\title{
The growth arrest and downregulation of c-myc transcription induced by ceramide are related events dependent on p21 induction, $\mathrm{Rb}$ underphosphorylation and E2F sequestering
}

Edoardo Alesse ${ }^{1,2}$, Francesca Zazzeroni ${ }^{1}$, Adriano Angelucci ${ }^{1}$, Giuseppe Giannini ${ }^{1}$, Lucia Di Marcotullio ${ }^{1}$ and Alberto Gulino ${ }^{1}$

\footnotetext{
1 Department of Experimental Medicine, University of L'Aquila, L'Aquila, Italy 2 corresponding author: Dr. E. Alesse, Department of Experimental Medicine, via Vetoio-Coppito II, 67100 L'Aquila. tel: 0862 433555; fax: 0862433523
}

Received 3.8.97; revised 24.11.97; accepted 5.12.97 Edited by R.A. Knight

\begin{abstract}
Ceramide is an intracellular lipid mediator generated through the sphingomyelin cycle in response to several extracellular signals. Ceramide has been shown to induce growth inhibition, c-myc downmodulation and apoptosis. In this paper we examined the mechanism by which ceramide induces growth suppression and the role of the G1-CDK/ $\mathrm{pRb} / \mathrm{E} 2 \mathrm{~F}$ pathway in this process. The addition of exogenous, cell-permeable $\mathrm{C}_{2}$-ceramide to the $\mathrm{Hs} 27$ human diploid fibroblast cell line resulted in a dose-dependent induction of the $221^{\mathrm{WAF} 1 / \mathrm{CIP} 1 / \mathrm{Sdi1}}$ kinase inhibitor with reduction of cyclin-D1 associated kinase activity. Furthermore, significant dephosphorylation of $\mathrm{pRb}$ was observed, with increased association of $\mathrm{pRb}$ and the E2F transcription factor into a transcriptionally inactive complex. Ceramide was also capable of inhibiting the transcriptional activity of a CAT reporter vector driven by E2F binding sites containing c-myc promoter transfected into $\mathrm{Hs} 27$ cells. The requirement of the $\mathrm{pRb}$ protein for ceramide-induced c-myc downregulation was supported by the failure of ceramide to inhibit promoter activity in HeLa cells, in which pRb function is abrogated by the presence of the E7 Papilloma virus oncoprotein, and in pRbdeleted SAOS2 AT cells. Ceramide-induced downregulation of the c-myc promoter was restored in SAOS2 \#1 cells in which a functional $\mathrm{Rb}$ gene was reintroduced. Our studies demonstrate that $\mathrm{pRb}$ dephosphorylation, induced by ceramide, is at least partly necessary for c-myc downregulation, and therefore the CDK-Rb-E2F pathway appears to be a target for the ceramide-induced modulation of cell cycle regulated gene transcription.
\end{abstract}

Keywords: ceramides, growth arrest, c-myc, p2 ${ }^{\mathrm{WAF} 1 / \mathrm{CIP} 1 / \mathrm{Sdi} 1}$

Abbreviations: TNF $\alpha$, tumor necrosis factor $\alpha$; pRb, Retinoblastoma gene product; MTS, (3-(4,5-dimethylthiazol-2-yl)-5-(3-carboxymethoxyphenyl)-2-(4-sulfaphenil)-2H-tetrazolium; $\mathrm{C}_{2}$-ceramide,
$\mathrm{N}$-acetylsphingosine; $\mathrm{DH}-\mathrm{C}_{2}$ ceramide, dihydro- $\mathrm{N}$-acetylsphingosine

\section{Introduction}

Sphingolipids constitute an important class of lipid molecules with important roles in tissue development, oncogenesis, cell growth, differentiation and apoptosis (Ballou, 1992a; Hannun, 1994; Kolesnick and Golde, 1994). In addition, sphingolipids have been reported to generate a senescent cellular phenotype in human cell lines (Venable et al, 1995).

Ceramide, a product of sphingomyelin hydrolysis, has recently emerged as a candidate intracellular mediator in response to several cellular stimuli such as TNF $\alpha$ (Dressler et al, 1992), IL1 $\beta$ (Mathias et al, 1993), $\gamma$ IFN (Kim et al, 1991), p75 LNGFR (Dobrowsky et al, 1994) and hydroxiD ${ }_{3}$ (Okazaki et al, 1990) and it has been shown to mediate several biochemical activities, such as phosphorylation of the EGF receptor (Goldkorn et al, 1991), induction of cyclooxygenase (Ballou et al, 1992b), downregulation of c-myc (Wolff et al, 1994), modulation of the activity of protein kinases (CAPK) and phosphatases (CAPP) (Mathias et al, 1991; Dobrowsky and Hannun, 1992; Dobrowsky et al, 1993). Furthermore, ceramide-activated protein kinase has been shown to phosphorylate Raf on thr 269, increasing its activity upon MEK (Yao et al, 1995). Requirement for ceramide in signalling through SAPK/JNK has also been described in stress-induced apoptosis (Verheij et al, 1996). Finally, ceramide is a potential modulator of the nuclear kB activity (Yang et al, 1993), involved in the regulation of several cellular and viral genes.

At the cellular level ceramide has been shown to exert an antiproliferative effect, similar to the G0/G1 arrest observed in response to withdrawal of essential serum factors associated with suppression of c-myc expression. $\mathrm{C}-m y c$ is one of the cell cycle regulated genes and is involved in cell proliferation, differentiation and apoptosis (Marcu et al, 1992; Packhman and Cleveland, 1995; Evan et al, 1992; Gu et al, 1994). In addition to growth arrest, ceramide is a strong inducer of apoptosis, and the prevalent effect depends on the doses and the cell types used in different experiments (Papp et al, 1994; Obeid et al, 1993).

Cell cycle control occurs mainly through the sequential activation of cyclin-dependent protein kinases (CDKs) which are programmed to phosphorylate regulatory proteins, thereby triggering events required for the G1-S transition. The decision to proceed beyond the late $\mathrm{G} 1$ appears to be executed by phosphorylating and thereby inactivating the product of the retinoblastoma gene $(p R b)$, 
whose growth-restraining role in early to mid-G1 reflects its ability to sequester a series of transcription factors the activities of which are required to induce expression of Sphase genes (Sherr et al, 1994; Lukas et al, 1996).

In fact, the molecular mechanism of Rb-dependent growth suppression is suggested to rely on physical interaction between the underphosphorylated $\mathrm{Rb}$ protein and the cellular transcription factor E2F. In fact, E2F plays a central role in the control of cell proliferation (Chellappan, 1994) and in the control of transcription of several growth-associated genes, including c-myc, N-myc, B-myb, cdc2, DHFR, thymidilatesynthetase, thymidine-kinase and DNA polymerase $\alpha$ genes, which contain E2F-binding sites in their regulatory regions (Blake and Azizkhan, 1989; Dalton, 1992; Helin and Harlow, 1993; Mudryj et al, 1990; Moran, 1993; Nevins, 1992; Pearson et al, 1991; Thalmeier et al, 1989; Vairo et al, 1995). Some of the latter genes have been shown to require E2F for their cell-cycle dependent expression while the transcriptional activity of E2F is inhibited by proteins of the retinoblastoma family, such as the retinoblastoma suppressor protein (pRb), p107 and p130 (Chellappan et al, 1991; La Thangue, 1994; Lees et al, 1992; Qin et al, 1992; Sardet et al, 1995). Inhibition of E2F activity is paralleled by cell growth suppression by retinoblastoma family members. The tumor suppression function of $\mathrm{pRb}$ also appears to correlate with its ability to repress E2F-dependent transcription. Naturally occurring mutants, which have lost $\mathrm{pRb}$ function, as well as the wild type $\mathrm{pRb}$, which interacts with viral oncogenic proteins like E1A of Adenovirus or E7 of Papilloma virus, are unable to regulate E2F (Arroyo and Raychaudhuri, 1992; Hiebert, 1993). In the physiological cellular context, the growth inhibitory properties of $\mathrm{pRb}$ are eliminated by CDKdependent phosphorylation of the protein (Chellappan et al, 1991; DeCaprio et al, 1989; Dynlacht et al, 1994; Hunter and Pines, 1991) that subvert its ability to bind to and inactivate E2F. Recently, a family of CDK inhibitors has been identified. Well characterized members of this family are p21, p27 and p57. The cDNA of p21 was cloned by virtue of encoding an overexpressed transcript in senescent human fibroblasts (Noda et al, 1994), a p53-inducible transcript (El-Deiry et al, 1993) and a Cdk2-associated protein (Xiong et al, 1993). p21 inhibits the activity of CDK-cyclin complexes and the onset of DNA replication. p21 probably blocks DNA replication, at least in part, by inhibiting $\mathrm{pRb}$ phosphorylation, followed by inhibition of E2F activation in late G1.

Although ceramide has been reported to induce $R b$ underphosphorylation (Dbaibo et al, 1995) and to downregulate cell growth, as well as cell cycle regulated genes (e.g. c-myc), there is only marginal information about the biochemical and molecular pathways involved. This prompted us to study whether c-myc regulation might be linked to the phosphorylation status of $\mathrm{Rb}$ and whether the effect of ceramide might be mediated by modulation of the cellular levels of the kinase inhibitors p21 and p27. Our results suggest that the observed ceramide-induced c-myc downregulation is likely to be generated at the transcriptional level through a mechanism involving different steps: (i) up-regulation of the p21 kinase inhibitor; (ii) reduction of cyclin D1-regulated kinase activities; (iii) Rb underphosphorylation; (iv) reduced availability of transcriptionally functional E2F for the two E2F sites located in the c-myc regulatory region with subsequent decrease of $c-m y c$ transcription. Therefore, the CDK-Rb-E2F pathway appears to be a target for the ceramide induced regulation of cell cycle regulated gene transcription.

\section{Results}

\section{Ceramide induces growth arrest and apoptosis in Hs 27 human fibroblasts}

In order to analyze the biochemical pathway through which ceramide induces its antiproliferative or apoptotic activity, we used young Hs 27 human diploid fibroblasts (20-30 passages) growing rapidly as shown by the (3- $(4,5-$ dimethylthiazol-2-yl)-5(3-carboxymethoxyphenyl)-2-(4-sulfophenyl) $-2 \mathrm{H}$-tetrazolium, inner salt (MTS) assay. The cell cultures were analyzed for apoptosis, one of the major biological effects of ceramide (Figure 1A). The number of apoptotic fibroblasts increased progressively with the dose of ceramide added to the cultures and with the time of treatment; up to $26 \%$ of apoptotic cells were observed at $48 \mathrm{~h}$ with $30 \mu \mathrm{M}$ $\mathrm{C}_{2}$-ceramide as analyzed by microscopic count after $\mathrm{AO} / \mathrm{EtBr}$ staining. In control cells treated with $30 \mu \mathrm{M} \mathrm{DH}-\mathrm{C}_{2}$ ceramide, no apoptosis was detected at the same time intervals. $\mathrm{DH}-\mathrm{C}_{2}$ ceramide is a biologically inactive homologue of $\mathrm{C}_{2}$-ceramide which lacks the trans-double bond at $\mathrm{C}_{4}-\mathrm{C}_{5}$ of the sphyngoid base backbone. Remarkedly, treatment of $\mathrm{Hs} 27$ with cellpermeable $\mathrm{C}_{2}$-ceramide (5 and $\left.30 \mu \mathrm{M}\right)$ also induced a dosedependent inhibition of cell proliferation, whereas no replicative arrest was observed after $\mathrm{DH}-\mathrm{C}_{2}$ ceramide treatment (Figure 1B).

\section{Effect of ceramide on CKI levels and on CDKs activities}

Whole cell extracts from the above culture were subjected to SDS-PAGE, followed by electrotransfer onto nitrocellulose, and the level of the different proteins involved in cell cycle regulation were analyzed.

The major finding of our experiments is shown in Figure 2 , where crude extracts from control $\left(\mathrm{DH}-\mathrm{C}_{2}\right.$ ceramide $30 \mu \mathrm{M})$ or treated cells $\left(\mathrm{C}_{2}\right.$-ceramide 5 and $\left.30 \mu \mathrm{M}\right)$ were analyzed for p27 and p21 levels after an $8 \mathrm{~h}$ exposure to the drug. This experiment demonstrated that whereas a slight decrease in p27 (Figure 2B) was induced by ceramide, a significant increase of p21 was observed in the same sample (Figure 2A). The p21 increase may represent the biochemical connection between ceramide treatment and proliferative arrest, since p27 and p21 kinase inhibitory action converge together to generate the G1inhibitory outcome of kinase regulation. Therefore, we evaluated the kinase activity (Figure 3 ) in immunoprecipitates with anti-cyclin D1 MAb by an in vitro kinase assay. The D1-associated kinase activity was strongly reduced after ceramide treatment when assayed either on histone$\mathrm{H} 1$ (Figure 3A) or on the physiological substrate recombinant $\mathrm{pRb}$ (Figure $3 \mathrm{~B}$ ). When the same immunoprecipitates were subjected to analysis for the presence of p21 in the complexes, an increased amount of this kinase 
A

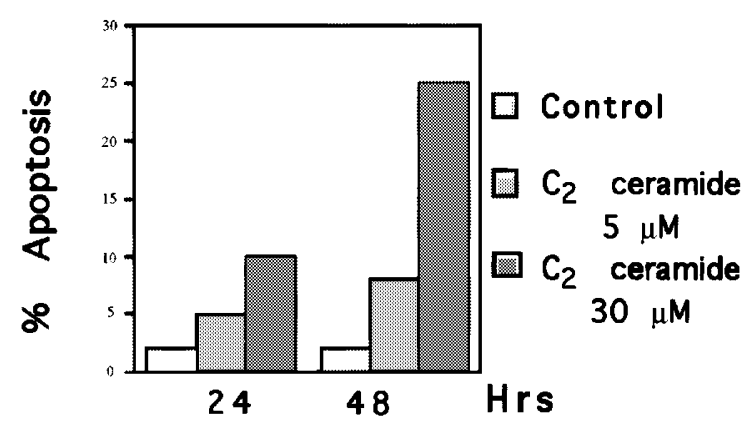

B

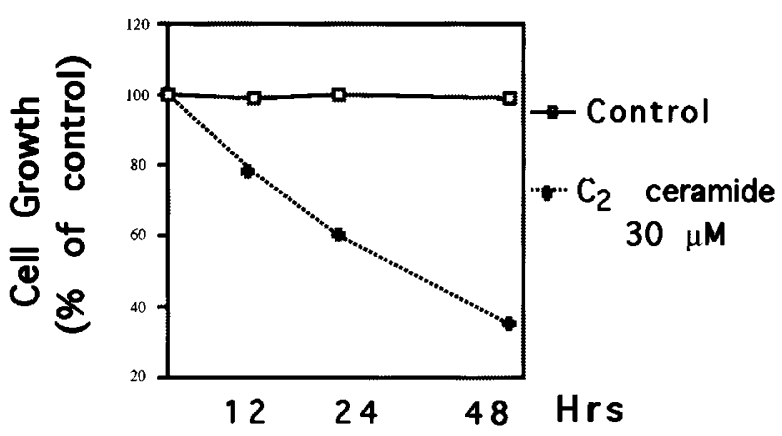

Figure 1 Effect of $\mathrm{C}_{2}$-ceramide on apoptosis and growth of $\mathrm{Hs} 27$ human diploid fibroblast. Growing $\mathrm{Hs} 27$ at about $22 \mathrm{PD}$ were treated with $\mathrm{DH}-\mathrm{C}_{2}$ ceramide $\left(30 \mu \mathrm{M}\right.$ as control) or $\mathrm{C}_{2}$-ceramide $(5$ or $30 \mu \mathrm{M})$ and analyzed for apoptosis and cell growth after 24 and $48 \mathrm{~h}$. (A) the evaluation of apoptosis was performed on living cells using $\mathrm{AO} / \mathrm{Etbr}\left(100 \mu \mathrm{g} / \mathrm{ml}\right.$ each) and fluorescence microscopy. For each determination 400 cells were examinated (DH- $\mathrm{C}_{2}$ ceramide $30 \mu \mathrm{M}, \mathrm{C}_{2}-\mathrm{Ceramide} \mu \mathrm{M}$, $\mathrm{C}_{2}$-ceramide $30 \mu \mathrm{M}$ ) and the experiment was performed in triplicate. In one separate experiment similar data were confirmed by cytofluorimetric analysis. (B) a colorimetric (MTS) assay was used to evaluate the cell proliferation over time. The data showed are representative of three different experiments. The difference observed either on proliferation and apoptosis at 24 and $48 \mathrm{~h}$ between treated and control were statistically significant $(P<0.01)$

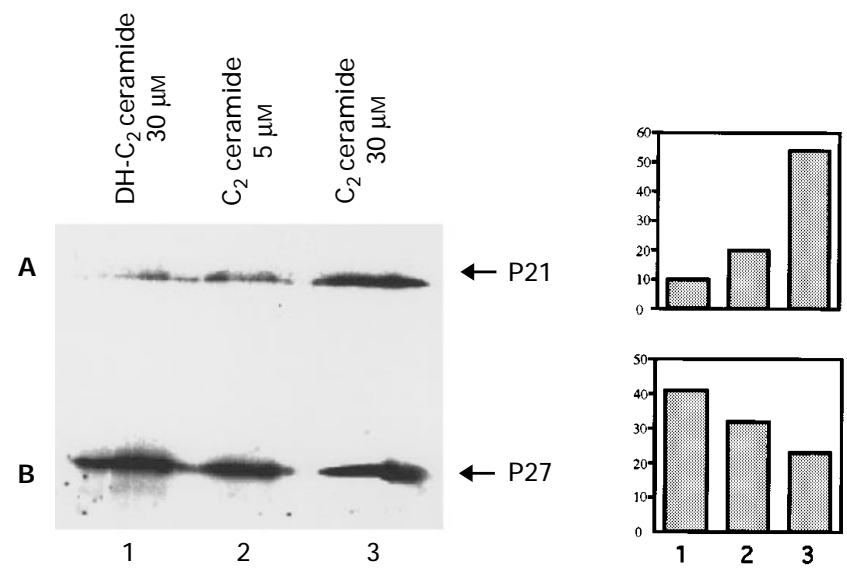

Figure 2 Western blot analysis for the peptide reactive with anti-p21 (A) and anti-p27 (B) monoclonal antibodies in total cell extracts from Hs 27 diploid fibroblasts treated with $\mathrm{DH}-\mathrm{C}_{2}$ ceramide $(30 \mu \mathrm{M}$, lane 1$)$, or with $\mathrm{C}_{2}$-ceramide $(5 \mu \mathrm{M}$, lane 2 or $30 \mu \mathrm{M}$, lane 3$)$. Actively proliferating Hs 27 cells were treated with ceramides in medium containing $10 \%$ fetal calf serum. After $8 \mathrm{~h}$ cells were lysed and the protein extract analyzed in immunoblot. Increased levels of p21 $1^{\text {WAF1,CIP, Sdi1 }}(\mathbf{A})$ and a small decrease of p27 kinase inhibitor (B) were detected in three separate experiments. The right half of each panel represents the densitometric analysis of the bands resulting from $E C L$ reaction after autoradiography. Statistical analysis comparing the optical density of the band was performed and the p21 increase was significant $(P<0.01)$. By contrast the p27 decrease was not statistically significant

inhibitor associated with cyclin D1 was detectable after ceramide treatment compared to the control (Figure $3 \mathrm{C}$ ). This result may indicate that in rapidly growing fibroblasts, treated with $\mathrm{C}_{2}$-ceramide, the level of p21 associated with cyclin D1 strictly determines the cyclin D1-dependent kinase activity.

\section{Ceramide determines $\mathbf{R b}$ underphosphorylation}

Considering that $\mathrm{pRb}$ is one of the most relevant targets for the $\mathrm{G} 1$ kinases, we evaluated the phosphorylation status of this tumor suppressor protein, in Western blot analysis, by using whole cell extracts from the control or ceramide-treated $\mathrm{Hs} 27$ cells. As shown in Figure 4, the treatment with $\mathrm{DH}-\mathrm{C}_{2}$ ceramide (30 $\mu \mathrm{M}$, lane 1) was ineffective in inducing $\mathrm{Rb}$ modification, whereas a progressive loss of phosphate groups was apparent at increasing $\mathrm{C}_{2}$-ceramide concentrations (5 and $30 \mu \mathrm{M})$, as indicated by the shift in the mobility of the $\mathrm{pRb}$ MAb immunoreactive bands (Figure 4 lanes 2 and 3).

\section{Effect of ceramide on pRb-E2F complexes and E2F DNA binding activity}

Underphosphorylated $\mathrm{pRb}$ has been reported to form specific complexes with polypeptide partners, including E2F. The result of this interaction is the functional inactivation of the transacting factor with concomitant modification of the E2F DNA binding activity. To evaluate whether ceramide-induced underphosphorylation of $\mathrm{Rb}$ was able to induce the formation of $\mathrm{Rb}-\mathrm{E} 2 \mathrm{~F}$ complexes and to influence E2F binding to a specific DNA consensus sequence, we tried two different approaches. First, we tested the levels of E2F-pRb complexes in control $\left(\mathrm{DH}-\mathrm{C}_{2}\right.$ ceramide, $\left.30 \mu \mathrm{M}\right)$ and $\mathrm{C}_{2-}$ ceramide $(30 \mu \mathrm{M})$ treated cells. Figure $5 \mathrm{~B}$ shows that ceramide treatment of $\mathrm{Hs} 27$ cells resulted in slightly increased levels of E2F-1 co-immunoprecipitated with $\mathrm{pRb}$. The increase in the amount of E2F associated to $\mathrm{pRb}$ was not a consequence of higher levels of cellular E2F-1 in ceramide treated cells vs untreated cells, as a slight decrease in the total amount of E2F-1 was observed after treatment (Figure $5 \mathrm{~A})$. These data suggest that ceramide is capable of increasing the levels of E2F-pRb complexes, even though the total levels of E2F1 are, per se, reduced. To study whether ceramide-stimulated E2F-pRb complex formation could modify E2F binding activity, we then tested whole cell extracts from $\mathrm{DH}-\mathrm{C}_{2}$ ceramide-treated or $\mathrm{C}_{2}$-ceramidetreated cells for the presence of the E2F DNA consensus sequence complexes (Figure $5 \mathrm{C}$ ) using electromobility shift assay (EMSA). By using the E2F consensus sequence $(-70$ 

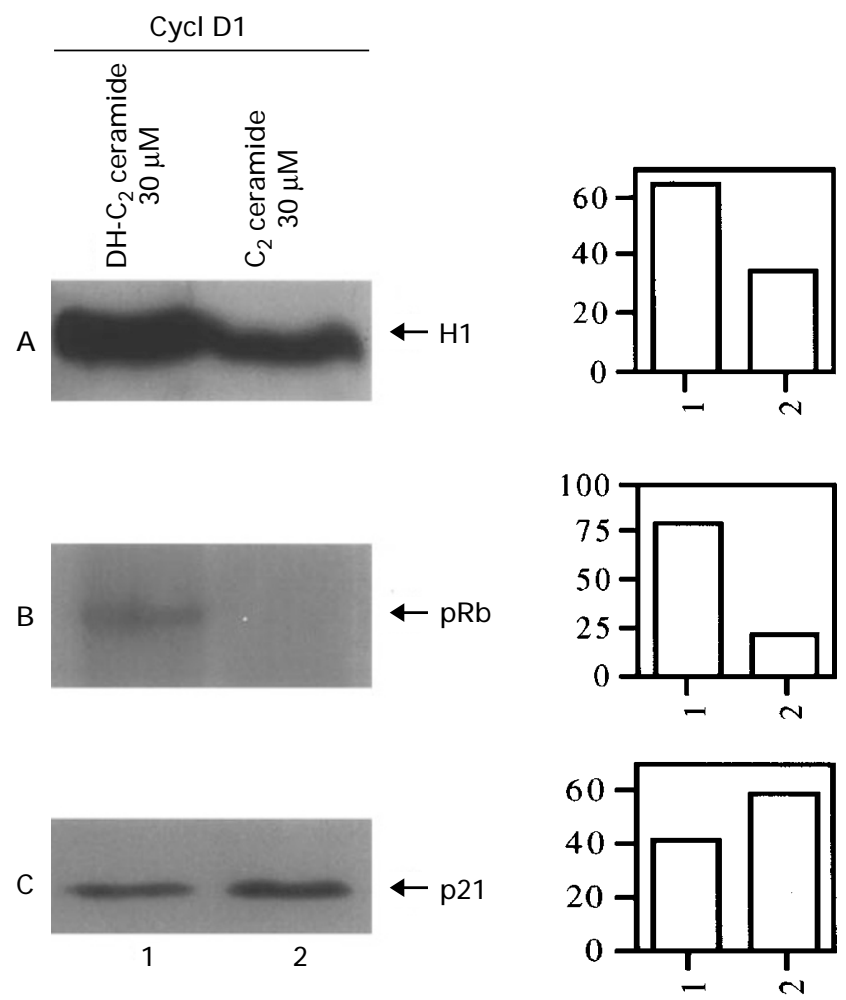

Figure 3 (A) In vitro kinase assay experiment to evaluate the kinase's activity associated with D1 cyclin. $\mathrm{H} 1$ histone was used as substrate for cellular kinase. Hs 27 were treated for $8 \mathrm{~h}$ with $\mathrm{DH}-\mathrm{C}_{2}$ ceramide $30 \mu \mathrm{M}$ (lane 1) or with $\mathrm{C}_{2}$ ceramide $30 \mu \mathrm{M}$ (lane 2). The cells were lysed and the proteins were immunoprecipitated with monoclonal antibody to cyclin D1. The cyclin associated kinases present in the immunoprecipitates were evaluated for their activity by the artificial phosphorylation of the $\mathrm{H} 1$ histone using the phosphate group of $\gamma^{32}$ P-ATP. (B) In vitro kinase assay to evaluate the kinase's activity associated with D1 cyclin on recombinant pRb. (C) Western blot analysis was performed with a p21 MAb to detect the immunoreactive peptides present in the $\mathrm{D} 1$ cyclin immunoprecipitate complexes after $\mathrm{DH}-\mathrm{C}_{2}$ ceramide or $\mathrm{C}_{2}$-ceramide treatment $(30 \mu \mathrm{M}, 8 \mathrm{~h})$. The right half of each panel represents the densitometric analysis of the autoradiograms. Similar results were observed in three different experiments. Whereas the result of $\mathbf{A}$ and $\mathbf{B}$ were statistically highly significant (optical density of $\mathrm{DH}-\mathrm{C}_{2}$ ceramide versus optical density of $\mathrm{C}_{2}$-ceramide, $\left.P<0.01\right)$ the result of $(\mathbf{C})$, even if consistently repeated, did not reach statistical significance

to $-30 \mathrm{bp}$ ) of the c-myc promoter, we observed a decrease in the E2F-DNA complexes after ceramide treatment compared to the control, probably due to the reduced E2F-1 levels. On the other hand, we were unable to detect an increase in the supershifted E2F-pRb complex after ceramide treatment, probably because of the low amount of residual E2F-1 protein. This suggests that ceramide impairs the transcription factor's ability to bind and transactivate the E2F cognate binding site of the c-myc promoter, either by reducing the levels of E2F1 or by inducing E2F association to pRB.

\section{Ceramide downregulates the transcriptional activity of the c-myc promoter: requirement for pRb}

To investigate whether the ceramide-induced $\mathrm{Rb}$ underphosphorylation, the reduction in the E2F1 levels, or both,

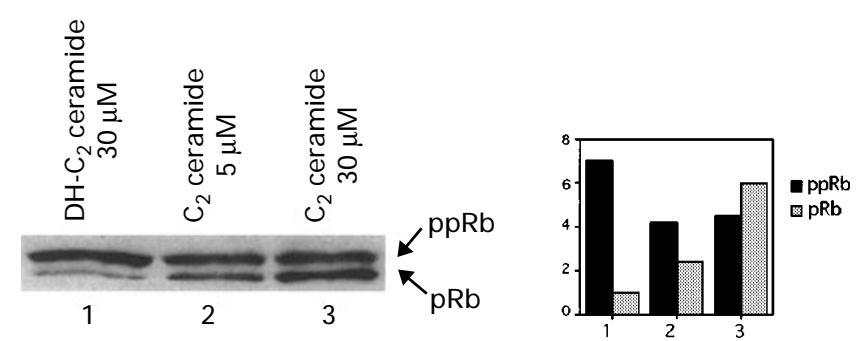

Figure $4 \mathrm{Rb}$ phosphorylation status in whole cell extract from $\mathrm{Hs} 27$ at about 22th passage. Western blot analysis was performed with anti-Rb MAb on crude extracts from control cells (treated with $\mathrm{DH}-\mathrm{C}_{2}$ ceramide $30 \mu \mathrm{M}$, lane 1 ), or from cells treated with $5 \mu \mathrm{M}$ (lane 2) or $30 \mu \mathrm{M}$ (lane 3 ) of $\mathrm{C}_{2}$-ceramide for $8 \mathrm{~h}$. The proteins were resolved on SDS-PAGE $(8.5 \%)$, transferred onto nitrocellulose and after immunoreaction resolved by ECL. The position of hypophosphorylated and hyperphosphorylated forms of $\mathrm{pRb}$ are indicated. A shift from the $\mathrm{Rb}$ phosphorylated form (lane 1) to underphosphorylated form was evident and dose dependent (lanes 2 and 3). Each lane was loaded with $50 \mu \mathrm{g}$ of total proteins and the amounts of protein loaded was confirmed by Ponceau S staining. Three different experiments confirmed this result. The right half of the figure is the schematic representation of the optical density of the bands. The black bars represent hyperphosphorylated $\mathrm{pRb}$ and the white bars the hypophosphorylated form

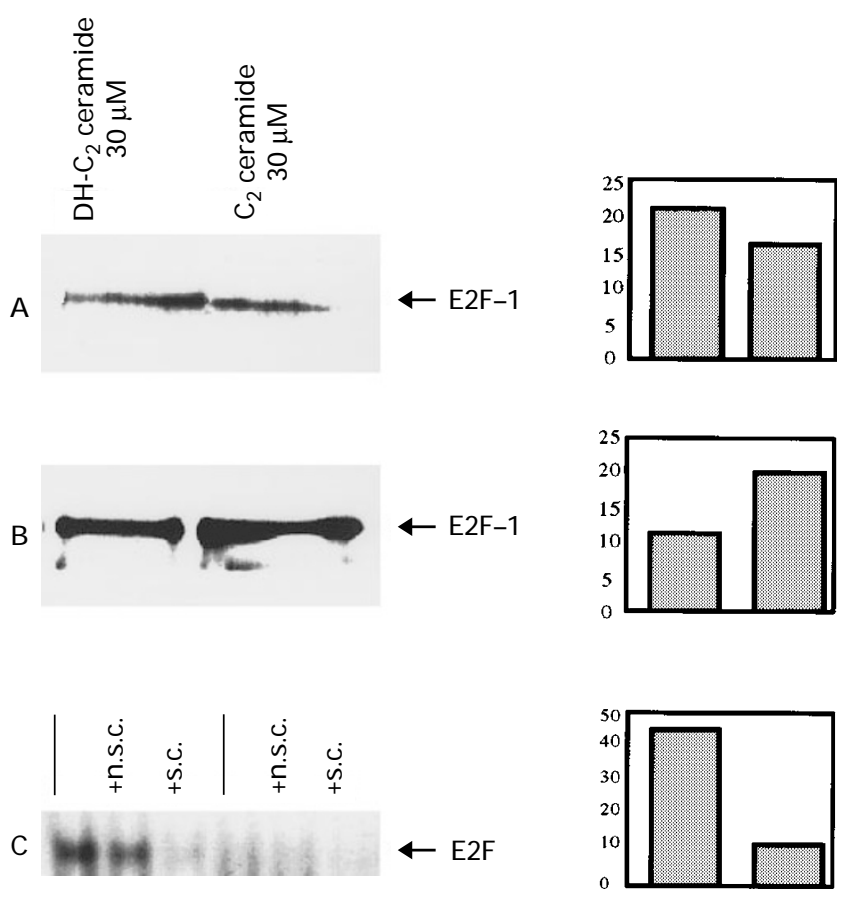

Figure 5 (A) Western blot analysis for E2F-1 levels in crude extract from Hs 27 cells treated with $\mathrm{DH}-\mathrm{C}_{2}$ ceramide $(30 \mu \mathrm{M})$ or $\mathrm{C}_{2}$-ceramide $(30 \mu \mathrm{M})$ for $8 \mathrm{~h}$. (B) Hs 27 crude extracts from cells treated with $\mathrm{DH}-\mathrm{C}_{2}$ ceramide or $\mathrm{C}_{2}$ ceramide as above were immunoprecipitated with anti-Rb MAb, resolved on SDS-PAGE, electrophoretically transferred onto nitrocellulose and analyzed for the amount of E2F-1 coimmunoprecipitated with $\mathrm{pRb}$ using anti-E2F-1 MAb. (C) E2F complexes in $\mathrm{Hs} 27$ whole cell extracts treated with $\mathrm{DH}-\mathrm{C}_{2}$ ceramide or $\mathrm{C}_{2}$-ceramide $(30 \mu \mathrm{M})$ detected by electromobility shift assay (EMSA). The probe used was an oligo matching the E2F site in the c-myc promoter. The specificity of the bands was determined by competition with either cold E2F-myc promoter site (specific competitor, s.c.) or E2F c-myc promoter mutated site (non specific competitor, n.s.c.). The right half of each panel represent the densitometric analysis of the specific bands $(\mathbf{A}, \mathbf{B}$ and $\mathbf{C}$, respectively) after autoradiography of one of three repeated experiments. The statistical analysis by comparing the optical density of the bands was performed (A: $P<0.05$, B and C: $P<0.01)$ 
correlated with the ceramide effect on c-myc gene transcription, we transfected Hs 27 cells with a reporter gene containing $250 \mathrm{bp}$ of the c-myc regulatory region including the $\mathrm{P} 1$ and the $\mathrm{P} 2$ promoters and the E2F sites upstream of the CAT coding sequence.

As shown in Figure 6, a significant reduction of c-myc promoter-driven CAT expression was observed in the Hs 27 cell line after $8 \mathrm{~h}$ of ceramide treatment (spots above lane 2 versus spots above lane 1), whereas no effect was detectable in HeLa transfected cells, harboring the oncogenic E6 and E7 proteins of the Papillomavirus, the latter being involved in $\mathrm{Rb}$ inactivation. Failure of ceramide to downregulate the c-myc promoter in HeLa cells suggests that sequestering of $\mathrm{pRb}$ by $\mathrm{E} 7$ proteins might be, at least partly, responsible for the lack of this effect in addition to E2F reduction. Therefore, to study whether $\mathrm{pRb}$ is required for ceramide-induced downregulation of the cmyc promoter, we transfected a c-myc promoter-CAT vector into the SAOS2 AT cell line harbouring a functionally significant $\mathrm{Rb}$ deletion, and into the SAOS2 \#1 cell line in which the full length gene was reintroduced, in the presence of either $\mathrm{C}_{2}$-ceramide or $\mathrm{DH}-\mathrm{C}_{2}$ ceramide. Figure $7 \mathrm{~A}$ shows that ceramide decreases the activity of the c-myc promoter in SAOS2 \#1 (first couple of spots versus second couple of spots), whereas no effect on gene expression is observed in SAOS2 AT (third couple versus fourth couple of spots). Figure $7 \mathrm{C}$ represents the Western blot analysis of $\mathrm{pRb}$ in SAOS2 \#1 and SAOS2 AT extracts. In addition to the endogenously deleted p95 pRb, the SAOS2 \#1 cell line also expresses low levels of the exogenous p105 Rb. Remarkedly, HeLa and SAOS2 AT cells were resistant to growth suppression and cell cycle arrest observed after ceramide treatment in cells harbouring functional $\mathrm{Rb}$.

Our observations suggest that the effect of ceramide requires the presence of a functional $\mathrm{pRb}$ which, by interacting with E2F, prevents the transcription factor from transactivating the $\mathrm{c}-\mathrm{myc}$ promoter.

\section{Discussion}

Recent studies have demonstrated that withdrawal of serum factors from cultures of different cell types induces growth arrest (Marcu et al, 1992) associated with a significant increase in ceramide content (Jayadev et al, 1995). This finding strongly suggests that ceramide plays a role in mediating the growth suppressive effects of serum deprivation. At the same time, it is well known that starvation, as well as ceramide, induces downregulation of the c-myc oncogene (Wolff et al, 1994; Packhman and Cleveland, 1995). The role of this oncogene in regulating cell proliferation, differentiation and other important functions has recently been well established (Marcu et al, 1992; Packhman and Cleveland, 1995; Evan et al, 1992; Gu et al, 1994).

In this paper we analyze the biochemical steps leading to c-myc downregulation following ceramide treatment, with its obvious consequences in cell cycle progression. An interesting approach to study the antiproliferative properties of ceramide is to investigate whether its administration to cells modifies the levels, or the function, of cell cycle controlling proteins. At first, we analyzed the levels of p21 and p27 to comprehend the subsequent modulation of the G1 cyclin-dependent kinase activities. Since $p R b$ is the most important protein substrate for CDKs phosphorylation during G1-S transition, we also analyzed the phosphorylation status of this protein. The major finding of our investigations is the dose-dependent increase in p21 levels induced by ceramide. With respect to the mechanism of p21 induction during ceramide treatment, we are
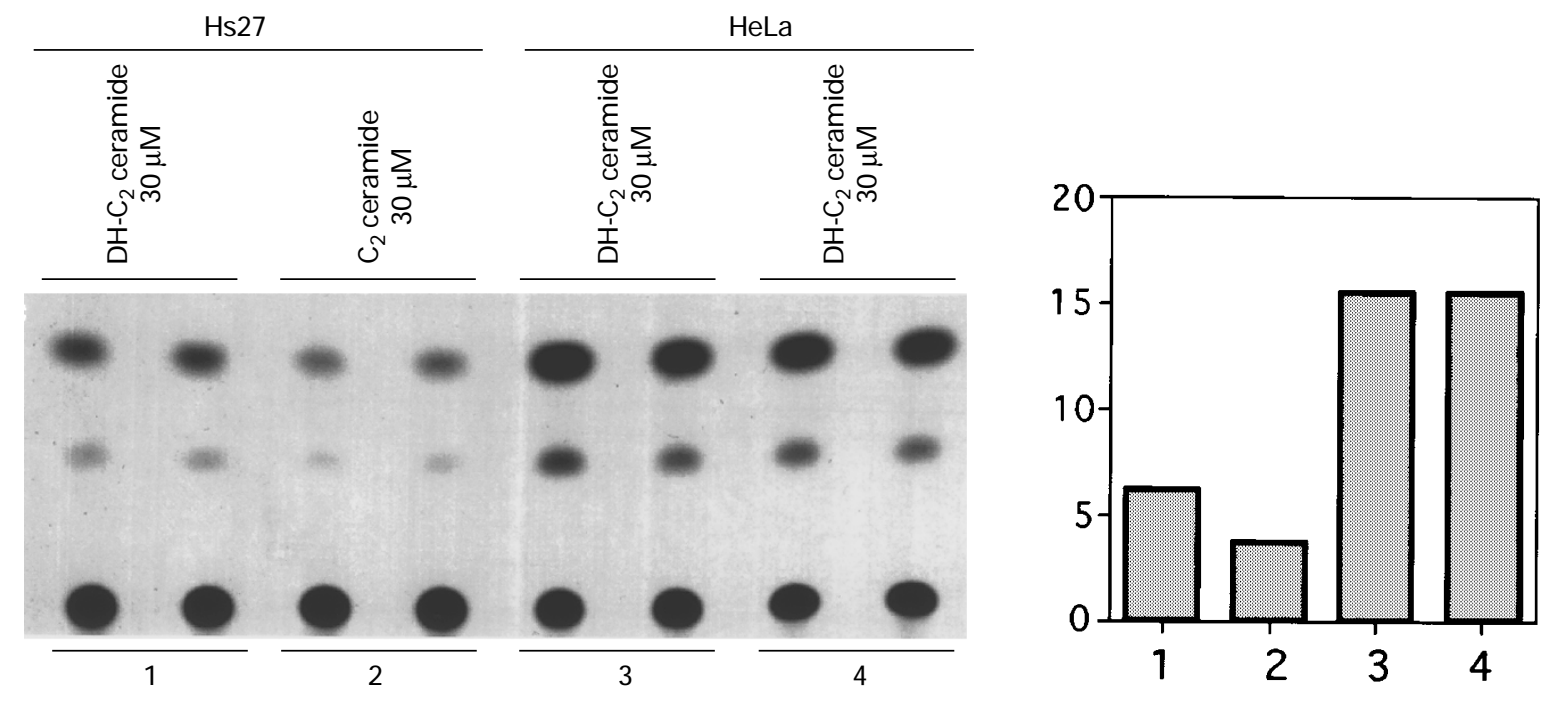

Figure 6 Transfection experiment using two different cell lines: Hs 27 (1-2) and HeLa (3-4). A myc CAT reporter gene, containing a 250 bp region encompassing the P1 and the P2 promoter of the gene, was introduced by DOTAP into the cells. After $48 \mathrm{~h}$, the medium was replaced and DH- $\mathrm{C}_{2}$ ceramide $(1$ and 3 ) or $\mathrm{C}_{2}$-ceramide (2 and 4 ) were added at the final concentration of $30 \mu \mathrm{M}$. Each treatment was performed in duplicate. After further $8 \mathrm{~h}$, the cells were harvested and proteins extracted by conventional protocol. The level of CAT activity was determined by the acetylation of $\left[{ }^{14} \mathrm{C}\right] \mathrm{chloroamphenicol}$. All cells were cotransfected with $\mathrm{pCH} 110$ as internal control for transfection efficiency. CAT activities were quantified by autoradiography followed by scanning radioactive acetylated spots (right half of the figure). The experiment was repeated three times and the difference in CAT expression after $\mathrm{C}_{2}$-ceramide treatment of $\mathrm{Hs} 27$ cells was statistically significant $(P<0.01)$ 


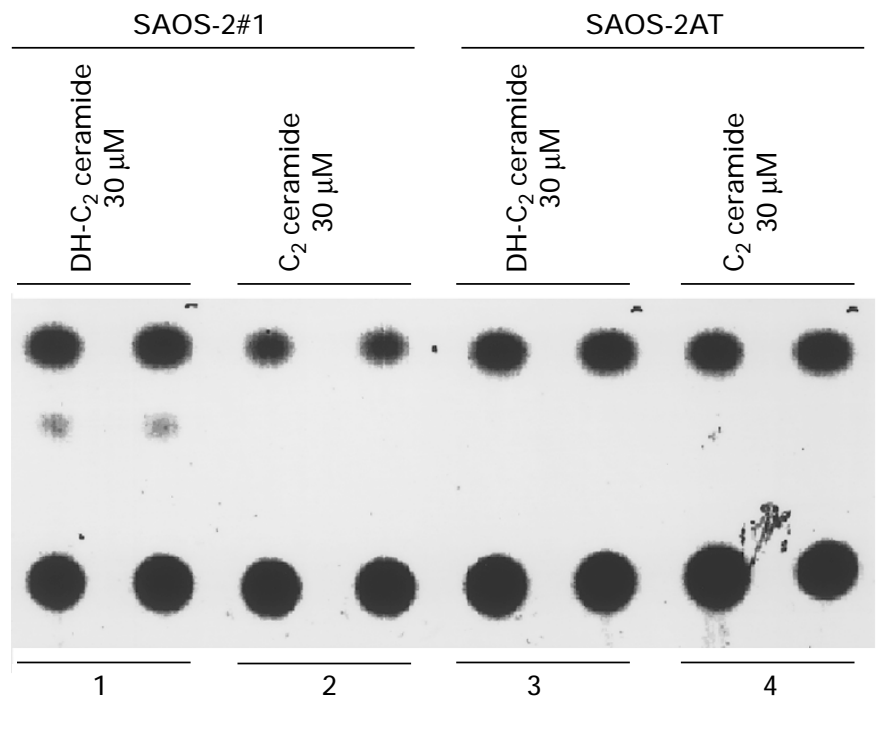

A
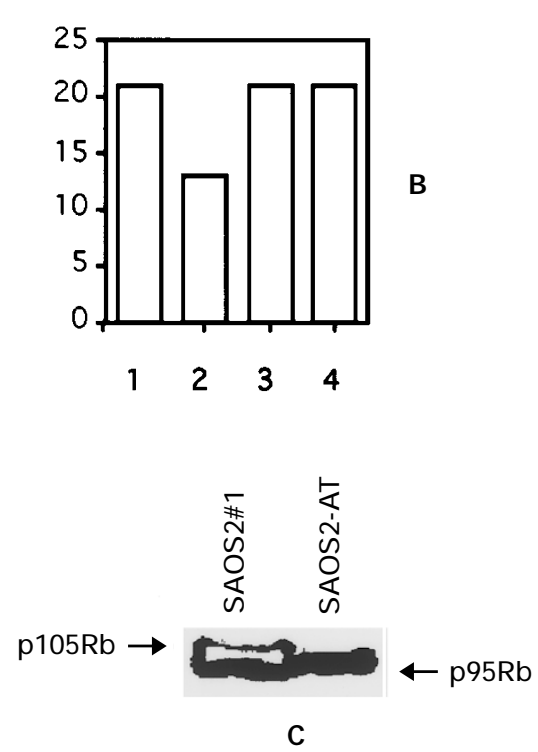

Figure 7 (A) Transfection of SAOS2\#1 (1-2) in which a functional Rb gene has been reintroduced, and SAOS2 AT (3-4), a pRb deleted osteosarcoma cell line, with c-myc-CAT plasmid. $10 \mu \mathrm{g}$ of construct were introduced by DOTAP into subconfluent cultures. After $48 \mathrm{~h}$, the medium was replaced and DH- $\mathrm{C}_{2}$ ceramide ( 1 and 3 ) or $\mathrm{C}_{2}$-ceramide (2 and 4) were added (final concentration $30 \mu \mathrm{M}$ ). Each treatment was performed in duplicate. After $8 \mathrm{~h}$ the cells were harvested and proteins extracted by a conventional protocol. CAT activities were quantified by autoradiography followed by scanning radioactive acetylated spots (B). A plasmid ( $\mathrm{pCH} 110$ ) was cotransfected to monitor transfection efficiency. Two different experiments were performed obtaining similar results and the difference between the optical density of couple 1 versus couple 2 was statistically significant. (C) Protein extracts prepared from parented SAOS2 AT cell line and from SAOS2 \#1 were analzyed by Western blot for $\mathrm{pRb}$ expression. The partially deleted endogenous $\mathrm{p} 95 \mathrm{Rb}$ and the exogenous $\mathrm{p} 105 \mathrm{Rb}$ are indicated

actually analyzing the effect of ceramide at the transcriptional level of p21 regulation. Nevertheless, since ceramide is a pleiotropic molecule able to modulate several biochemical pathways, other mechanisms to explain p21 upregulation cannot be excluded. p21 upregulation might, per se, unequivically explain the cascade of molecular and biological events observed after ceramide treatment. In fact, p21 is a potent inhibitor of CDKs activity and cell proliferation. Furthermore, the inhibition of cyclin D1 dependent kinase by ceramide correlates with $\mathrm{Rb}$ underphosphorylation and E2F association into an inactive transactivation $\mathrm{pRb}-\mathrm{E} 2 \mathrm{~F}$ complex. In addition, recent data suggest that the inhibition of cyclin-dependent kinases by p21 is an upstream event that downregulates the expression of E2F1 and of E2F-dependent transcription (Good et al, 1996). Consistent with our results, a recent report showed that p21 inhibits E2F-dependent transcription of several genes involved in cell cycle progression (Shiyanov et al, 1996). The regulatory region of the c-myc proto-oncogene contains two E2F binding sites, between the two major promoters, which are regulated during cell cycle progression in response to proliferate siganls (Pearson et al, 1991), and which are down-modulated by growth factor deprivation (Marcu et al, 1992) also resulting in a rise in intracellular ceramide (Jayadev et al, 1995). Therefore, we chose this gene as a model to investigate ceramide effects on the transcription of genes involved in cell cycle progression. We demonstrated that ceramide reduces binding of E2F to the cognate binding site located in the c-myc promoter and reduces its transcriptional activity only in cells harbouring a functional $\mathrm{Rb}$ protein (Hs 27, SAOS2 \#1). On the contrary, this effect was not observed in cells lacking pRb (HeLa and SAOS2 AT) in which the $p R b-E 2 F$ pathway is inactivated. On the basis of our results, we believe that $p R b$ inactivation of $E 2 F$, in addition to the reduction of E2F1, is responsible for the observed c-myc downregulation.

In conclusion, the p21 modulated cyclin-dependent kinase-pRb-E2F pathway appears to be a target for the ceramide-induced regulation of cell cycle dependent genes. We also suggest that c-myc downmodulation induced by ceramide might represent a general model for gene regulation shared by all genes containing E2F sites in their regulatory regions. Since both $\mathrm{pRb}$ and E2F are members of gene families, with partially differentiated function, it would also be interesting to evaluate the effects of ceramide treatment on the function of other members of these families.

\section{Materials and Methods}

\section{Cell culture and proliferation}

Hs 27 human diploid fibroblasts and HeLa cells were obtained from ATCC (Gaithersburg, MD) and the Hs 27 were used in our experiment between passage 22 and 28. The cells were grown in Dulbecco's modified essential medium with the addition of $10 \%$ FCS, glutammine (2 $\mathrm{mM}$ ) and antibiotics (50 U/ml penicillin and $50 \mu \mathrm{g} / \mathrm{ml}$ streptomycin; Hyclone, Europe) at $37^{\circ} \mathrm{C}$ in a humidified incubator under $5 \% \mathrm{CO}_{2}$. The SAOS2 AT osteosarcoma cell line, which carries a naturally 
occurring Rb gene deletion (exons 21-27) and the SAOS2 \#1, a Rb reconstituted clone already described (Lukas et al, 1994; Fung et al, 1993), were grown in RPMI 1640 medium without or with geneticin $(50 \mathrm{ng} / \mathrm{ml})$ respectively.

Cell proliferation was measured in $\mathrm{Hs} 27$ cells grown on a 96 well flat bottom microtiter plate using the MTS colorimetric assay (Cell Titer 96 ${ }^{\mathrm{TM}}$ AQeous Non Radioactive Cell Proliferating Assay from Promega, Madison, WI) (Buttke et al, 1993).

\section{Morphological measurement of apoptosis}

Confluent cultures were assayed for apoptosis and necrosis by fluorescence microscopy following labeling with acridine orange and ethidium bromide, as described by Duke and Cohen (1992). Floating and attached cells were collected as described above and washed three times in PBS. One-ml aliquots of $1 \times 10^{6}$ cells were centrifuged $(300 \times g)$, the pellet was resuspended in $25 \mu \mathrm{l}$ of media, and $1 \mu \mathrm{l}$ of a dye mixture containing $100 \mu \mathrm{g} / \mathrm{ml}$ acridine orange and $100 \mu \mathrm{g} / \mathrm{ml}$ ethidium bromide prepared in PBS, and mixed gently. Ten $\mathrm{ml}$ of mixture were placed on a microscope slide and covered with a $22 \mathrm{~mm}^{2}$ coverslip and examined under $\times 40$ dry objectives using epillumination and filter combination. An observer blinded to the identity of treatments scored at least 200 cells/sample. Live cells were determined by the exclusion of ethidium bromide stain. At least 400 cells were counted from each condition (control or $\mathrm{C}_{2}$-ceramide treated cells) and apoptotic scoring was independently determinated by two observers. Each experiment was repeated three times.

\section{Immunoprecipitation}

Whole cell extracts $(100-200 \mu \mathrm{g})$ were incubated with anti-pRb monoclonal antibody (Santa Cruz Biotechnology, Heidelberg, Germany) for $1 \mathrm{~h}$ at $4^{\circ} \mathrm{C}$ in a buffer containing $20 \mathrm{mM}$ HEPES (pH 7.9), $40 \mathrm{mM} \mathrm{KCl}, 1 \mathrm{mM} \mathrm{MgCl} 2,0.1 \mathrm{mM}$ EGTA, $0.1 \mathrm{mM}$ EDTA, $0.5 \mathrm{mM}$ DTT and $3 \mathrm{mg} / \mathrm{ml} \mathrm{BSA}$. The mixtures were then further incubated with protein A/G plus Agarose (Santa Cruz Biotechnology, Heidelberg, Germany) for $1 \mathrm{~h}$ at $4^{\circ} \mathrm{C}$. The beads were centrifuged and washed four times with $0.8 \mathrm{ml}$ of the same buffer. The pellets were resuspended in loading buffer, resolved on $8.5 \%$ SDS-PAGE, transferred onto nitrocellulose and the filter was then used for Western analysis using anti-E2F1 monoclonal antibody (Santa Cruz Biotechnology, Heidelberg, Germany).

\section{Western blot analysis}

Cells treated with either $\mathrm{C}_{2}$-ceramide or $\mathrm{DH}-\mathrm{C}_{2}$ ceramide (Biomol, Plymouth Meeting, PA) for $8 \mathrm{~h}$ were washed twice with ice-cold phosphate buffer saline, scraped off plates into hypotonyc lysis buffer (20 mM Tris- $\mathrm{HCl} \mathrm{pH} 7.4,25 \mathrm{mM} \mathrm{NaCl}, 1 \mathrm{mM}$ sodium orthovanadate, $10 \mathrm{mM}$ sodium orthophosphate, $0.25 \mathrm{mM}$ EDTA, $0.5 \mathrm{mM}$ PMSF, $10 \mu \mathrm{g} / \mathrm{ml}$ leupeptine and $1 \%$ aprotinin) and then flash frozen in liquid nitrogen. After three cycles of freeze-thaw, the cells were passed several times through a $25 \mathrm{G}$ needle. Lysates were cleared by centrifugation at $15000 \times g$ for $30 \mathrm{~min}$, and protein concentrations were determined using the Biorad protein assay reagent (Biorad). Equal amounts of protein (usually $30 \mu \mathrm{g}$ ) were separated by SDS PAGE, electrophoretically transferred onto nitrocellulose (Schleicher and Schuell, Germany) and probed with mouse monoclonal anti-Rb, anti-p21, anti-p27, or anti-E2F1 (Santa Cruz Biotechnology, Heidelberg, Germany). Immunoreactive bands were visualized by enhanced chemioluminescence (ECL, Amersham, UK). The films were then subjected to densitometric analysis for quantification of band densities. In some experiments, we used the same filter for both the in vitro kinase assay of $\mathrm{H} 1$ histone and Western blot in order to detect the p21-D1 cyclin immunoprecipitated complexes (Santa Cruz Biotechnology, Heidelberg, Germany).

\section{In vitro kinase assay}

This assay was performed according to Harper (Harper et al, 1993). Briefly, whole cell extracts from $\mathrm{Hs} 27$ cells (10 centimetres subconfluent dish) treated with $\mathrm{C}_{2}$-ceramide or $\mathrm{DH}-\mathrm{C}_{2}$ ceramide $(20 \mu \mathrm{M})$ were obtained by lysis in $0.8 \mathrm{ml}$ RIPA buffer (PBS, $1 \%$ NP40, $0.5 \%$ sodium deoxycholate, $0.1 \%$ SDS and protease and phosphatase inhibitors). Each half of the extract was immunoprecipitated with cyclin D1 monoclonal antibodies (Santa Cruz Biotechnology, Heidelberg, Germany), and used for histone $\mathrm{H} 1$ (Sigma) or recombinant $\mathrm{pRb}$ (Santa Cruz Biotechnology) kinase assay in a $25 \mu \mathrm{l}$ reaction containing $65 \mathrm{mM}$ k- $\beta$-glycerophosphate $(\mathrm{pH} \mathrm{7.3),} 15 \mathrm{mM} \mathrm{MgCl}$, $15 \mathrm{mM}$ EGTA, $10 \mathrm{mM}$ DTT, $1 \mathrm{mg} / \mathrm{ml}$ ovalbumin, $0.5 \mathrm{mM} \mathrm{NaF}$, $0.1 \mathrm{mM}$ sodium orthovanadate, $5 \mu \mathrm{g} / \mathrm{ml}$ leupeptin and $0.4 \mathrm{nCi} / \mathrm{nmol}$ $\left[\gamma^{32}\right]$ ATP. Each reaction contained $2.5 \mu \mathrm{g}$ of histone $\mathrm{H} 1$ or $5 \mu \mathrm{g} \mathrm{pRb}$ and a quarter of the immunoprecipitates with cyclin D1. After $15 \mathrm{~min}$ at $37^{\circ} \mathrm{C}, 5 \mu \mathrm{l}$ aliquots were removed and spotted on phosphocellulose paper for quantification. The remainder of the aliquots were mixed with $15 \mu \mathrm{l}$ of $2 \times$ SDS buffer prior to SDS-PAGE and autoradiography.

\section{Cell transfections}

A myc-CAT construct containing two potential E2F binding sites was produced by placing a Notl-Mrol fragment from the human c-myc regulatory region $(250 \mathrm{bp})$ upstream of the CAT coding region of a conventional reporter gene (Basic CAT, Promega) after subcloning into the superpolylinker of the psL1180 plasmid (Pharmacia Biothec, Uppsala, Sweden). Hs 27, HeLa, SAOS2 AT and SAOS \#1 cells were grown to $70 \%$ confluency and transfected by DOTAP reagent (Boehringer Mannheim) with $10 \mu \mathrm{g}$ of myc-CAT construct. Forty-eight hours after transfection, fresh medium and $\mathrm{DH}-\mathrm{C}_{2}$ ceramide $(30 \mu \mathrm{M})$ or $\mathrm{C}_{2}$-ceramide $(30 \mu \mathrm{M})$ was added. Twelve hours later, the cells were washed with ice-cold PBS and scraped-off the plates. The pellets were resuspended in $100 \mu \mathrm{l}$ of Tris $0.25 \mathrm{M}\left(\mathrm{pH} \mathrm{8.0)}\right.$ ) and stored at $-80^{\circ} \mathrm{C}$ until used. Chloramphenicol acetyltransferase (CAT) assay was performed as described previously (Gorman et al, 1982). A pCH 110 plasmid (Pharmacia) was cotransfected to measure efficiency. CAT activities were quantified by autoradiography followed by scanning radioactive acetylated spots through phosphoimager.

\section{Extracts preparation and EMSA}

Whole cell extracts were prepared as described by Mudryj et al (1991), with some modifications. In short, cells were washed twice with cold phosphate buffered saline (PBS), scraped, and the pellet of approximately $5 \times 10^{7}$ was resuspended in $100 \mu \mathrm{l}$ of cell lysis buffer (10 mM HEPES pH 7.6, $50 \mathrm{mM} \mathrm{NaCl}, 5 \mathrm{mM} \mathrm{KCl}, 1.5 \mathrm{mM} \mathrm{MgCl}_{2}$, $0.5 \mathrm{mM} \mathrm{NaF}, 1 \mathrm{mM}$ DTT, $0.5 \mathrm{mM}$ PMSF, $0.5 \mathrm{mM} \mathrm{NaVO}_{4}$ ) and incubated in ice for $15 \mathrm{~min}$. The cells were homogenized in a Dounce (30 strokes) and then $100 \mu \mathrm{l}$ of extraction buffer (20 mM HEPES $\mathrm{pH} 7.6,1.6 \mathrm{M} \mathrm{NaCl}, 20 \%$ glycerol, $0.1 \mathrm{mM}$ EDTA, $0.5 \mathrm{NaF}, 0.5 \mathrm{mM}$ $\mathrm{NaVO}_{4}, 1 \mathrm{mM}$ DTT) were added. The extracts were rocked for $30 \mathrm{~min}$ at $4{ }^{\circ} \mathrm{C}$, and then centrifuged for $60 \mathrm{~min}$ in 50 a Ti rotor at 38000 r.p.m. The supernatants were removed and dialyzed at $4^{\circ} \mathrm{C}$ by $50 \mathrm{mM} \mathrm{NaCl}$. For E2F, an assay band shift was performed as already described (Mudryj et al, 1991). The probe was an E2F oligonucleotide $(0.2 \mathrm{ng} /$ reaction) representing the distal E2F binding site of the c-myc 
promoter $(-70$ to -30$)$ with the following sequence: 5 CGCTTGGCGGGAAAAAGAACGGAGGGAGGGATCGCGCTGAG. The mutated E2f site used for competition had the following sequence: 5'-GCTTGGATTGTTCAAGAACGGAGGGAGGGTACTGCTTGAG. $5 \mu \mathrm{g}$ of crude extract were preincubated for $10 \mathrm{~min}$ at room temperature in the binding reaction containing $20 \mathrm{mM}$ HEPES, $1 \mathrm{mM}$ $\mathrm{MgCl}_{2}, 0.1 \mathrm{mM}$ EDTA, $50 \mathrm{mM} \mathrm{NaCl}, 0.5 \mathrm{mM} \mathrm{DTT}, 100 \mathrm{ng}$ poly(dl-dC), and $50 \mu \mathrm{g} \mathrm{BSA}$. The ${ }^{32} \mathrm{P}$-labeled probe was then added and the incubation continued for 20 min. A mutant E2F oligo was used to test binding specificity. The DNA-protein complexes were resolved on a $5 \%$ polyacrylamide gel in $0.25 \times$ Tris-borate-EDTA (TBE) buffer, dried and autoradiographed.

\section{Acknowledgements}

We thank Dr YK Fung for providing the SAOS2 AT and SAOS2 \#1 cell lines, Dr I Trotta for artwork and Drs G Kroemer and ZC Di Rocco for helpful reading of manuscript. This work was supported by grants from the Associazione Italiana per la Ricerca sul Cancro (AIRC) and by the National Research Council (CNR), ACRO Project.

\section{References}

Arroyo M and Raychaudhuri P (1992) Retinoblastoma-repression of E2F-dependen transcription depends on the ability of the retinoblastoma protein to interact with E2F and is abrogated by the adenovirus E1A oncoprotein. Nucleic Acids Res. 20: $5947-5954$

Ballou LR (1992a) Sphingolipids and cell function. Immunol. Today 13: 339-341

Ballou LR, Chao CP, Holness MA, Barker SC and Raghow R (1992b) Interleukin-1mediated $\mathrm{PGE}_{2}$ production and sphingomyelin metabolism. Evidence for the regulation of cyclooxygenase gene expression by sphingosine and ceramide. J. Biol. Chem. 267: 20044-20050

Blake M and Azizkhan JC (1989) Transcription factor E2F is required for efficient expression of the hamster dihydrofolate reductase gene in vitro and in vivo. Mol. Cell. Biol. 9: 4994-5002

Buttke TM, McCubrey JA and Owen TC (1993) Use of an aqueous soluble tetrazolium/formazan assay to measure viability and proliferation of lymphokinedependent cell lines. J. Immunol. Methods 157: 233

Chellappan SP (1994) The E2F transcription factor: role in cell cycle regulation and differentiation. Mol. Cell. Differentiation 2: 201-220

Chellappan SP, Hiebert S, Mudryj M, Horowitz JM and Nevins JR (1991) The E2F transcription factor is a cellular target for $\mathrm{Rb}$ protein. Cell 65 : 1053-1061

Dalton S (1992) Cell cycle regulation of the human cdc2 gene. EMBO J. 11: 17971804

Dbaibo GS, Pushkareva MY, Jayadev S, Schwarz JK, Horowitz JM, Obeid LM and Hannun YA (1995) Retinoblastoma gene product as a downstream target for a ceramide-dependent pathway of growth arrest. Proc. Nalt. Acad. Sci. USA. 92 $1347-1351$

DeCaprio JA, Ludlow JW, Lynch D, Furukama Y, Griffin J, Piwnica-Worms H, Huang CM and Livingston DM (1989) The product of the retinoblastoma susceptibility gene has properties of a cell cycle regulatory element. Cell 58: 1085-1095

Dobrowsky RT and Hannun YA (1992) Ceramide stimulates a cytosolic protein phosphatase. J. Biol. Chem. 267: 5048-5051

Dobrowsky RT, Kamibayashi C, Mumby MC and Hannun YA (1993) Ceramide activates heterotrimeric protein phosphatase 2A. J. Biol. Chem. 268: 1552315530

Dobrowsky RT, Werner MK, Castellino AM, Moses VC and Hannun YA (1994) Activation of the sphingomyelin cycle through the low-affinity neurotrophin receptor. Science 265: 1596-1599

Dressler KA, Mathias S and Kolesnick RN (1992) Tumor necrosis factor- $\alpha$ activates the sphingomyelin signal transduction pathway in a cell-free system. Science 255: $1715-1718$

Duke RC and Cohen JJ (1992) Morphological and biochemical assay of apoptosis. In Current Protocols in Immunology, JE Coligan and AM Kruisbeak, eds. (New York: John Wiley \& Sons) pp. 3.17.1-3.17.16

Dynlacht BD, Flores O, Lees JA and Harlow E (1994) Differential regulation of E2F trans-activation by cyclin/cdk2 complexes. Genes Dev. 8: 1772-1786
El-Deiry WS, Tokino T, Velculesco VE, Levy DB, Parsons R, Trent JM, Lin D, Mercer WE, Kinzler KW and Wogelstein B (1993) WAF1, a potential mediator of p53 tumor suppression. Cell 75: 817-825

Evan GI, Wyllie AH, Gilbert CS, Littelewood TD, Land H, Brooks M, Waters CM, Penn LZ and Hancock D (1992) Induction of apoptosis in fibroblasts by c-myc protein. Cell 69: $119-128$

Fung Y-KT, Tang A, Murphree L, Zhang F-H, Qui W-R, Wang S-W, Shi S-H, Lee L, Driscoll B and Wu K-J (1993) The Rb gene suppresses the growth of normal cells. Oncogene 8: 2659-2672

Goldkorn T, Dressler KA, Muindi J, Radin NS, Mendelsohn J, Menaldino D, Liotta D and Kolesnick RN (1991) Ceramide stimulates epidermal growth factor receptor phosphorylation in AG31 human epidermoid carcinoma cells. J. Biol. Chem. 266: 16092-16097

Good L, Dimri GP, Campisi J and Chen KY (1996) Regulation of dihydrofolate reductase gene expression and E2F components in human diploid fibroblasts during growth and senescence. J. Cell Phys. 168: $580-588$

Gorman CM, Moffat LF and Howard BH (1982) Recombinant genomes which express chloramphenicol acetyltransferase in mammalian cells. Mol. Cell. Biol. 2: 10441051

Gu W, Bhatia K, Magrath IT, Dang CV and Dalla-Favera R (1994) Binding and suppression of the Myctranscriptional activational domain by 107 . Science 264 : $251-254$

Hannun YA (1994) The sphingomyelin cycle and the second messenger function of ceramide. J. Biol. Chem. 269: 3125-3128

Harper JW, Adami GR, Wei N, Keyomarsi K and Elledge SJ (1993) The p21 cdkinteracting protein cip 1 is a potent inhibitor of $\mathrm{G} 1$ cyclin-dependent kinases. Cell 75: $805-816$

Helin K and Harlow E (1993) The retinoblastoma protein as a transcriptional repressor. Trend Cell Biol. 3: 43-46

Hiebert S (1993) Regions of the retinoblastoma gene product required for its interaction with the E2F transcription factor are necessary for E2 promoter repression and pRb-mediated growth suppression. Mol. Cell. Biol. 13: 33843391

Hunter T and Pines J (1991) Cyclins and cancer. Cell 66: 1071-1074

Jayadev S, Liu B, Bielawska AE, Lee JY, Nazaire F, Pushkareva MY, Obeid LM and Hannun YA (1995) Role for ceramide in cell cycle arrest. J. Biol. Chem. 270: 2047-2052

Kim M, Linardic C, Obeid L and Hannun YA (1991) Identification of sphingomyelin turnover as an effector mechanism for the action of tumor necrosis factor $\alpha$ and $\gamma$ interferon. J. Biol. Chem. 266: 484-489

Kolesnick R and Golde DW (1994) The sphingomyelin pathway in tumor necrosis factor and interleukin-1 signaling. Cell 77: 325-328

La Thangue NB (1994) DRTF1/E2F: an expanding family of heterodimeric transcription factors implicated in cell-cycle control. Trends Biochem. Sci. 19: $108-114$

Lees E, Faha B, Dulic V, Reed SI and Harlow E (1992) Cyclin E/cdk2 and cyclin A/ cdk2 kinases associate with $\mathrm{p} 107$ and E2F in temporally distinct manner. Genes Dev. 6: $1874-1885$

Lukas J, Muller H, Bartkova J, Spitkovsky D, Kjierulff AA, Jansen-Durr P, Strauss M and Bartek J (1994) DNA tumor virus oncoptroteins and retinoblastoma gene mutations share the ability to relieve the cell's requirement for cyclin D1 function in G1. J. Cell Biol. 125: 625-638

Lukas P, Bartkova J and Bartek J (1996) Convergence of mitogenic signalling cascades from diverse classes of receptors at the cyclin D-cyclindependent kinase-pRb-controlled G1 checkpoint. Mol. Cell. Biology 16: 6917-6925

Marcu KB, Bossone SA and Patel AJ (1992) myc function and regulation. Annu. Rev. Biochem. 61: 809-860

Mathias S, Dressler KA and Kolesnick RN (1991) Characterization of a ceramideactivated protein kinase: stimulation by tumor necrosis factor $\alpha$. Proc. Natl. Acad. Sci. USA. 88: 10009-10013

Mathias S, Younes A, Kan C, Orlow I, Joseph Cand Kolesnick RN (1993) Activation of the sphingomyelin signaling pathway in intact EL4-cells and in a cell-free system by IL-1 $\beta$. Science 259 : $519-522$

Moran E (1993) DNA tumor virus transforming proteins and the cell cycle. Curr. Opin. Dev. 3: $63-70$

Mudryj M, Devoto SH, Hiebert SW, Hunter T, Pines J and Nevins JR (1991) Cell cycle regulation of the $E 2 F$ transcription factor involves an interaction with cyclin $A$. Cell 65: $1243-1253$ 
Mudryj M, Hiebert SW and Nevins JR (1990) A role for the adenovirus inducible E2F transcription factor in a proliferation dependent signal transduction pathway. EMBO J. 9: 2179-2184

Nevins JR (1992) E2F: a link between the Rb tumor suppressor protein and viral oncoproteins. Science 258: 424-429

Noda A, Ning Y, Venable SF, Pereira-Smith O and Smith JR (1994) Cloning of senescent cell-derived inhibitors of DNA synthesis using an expression screen. Exper. Cell Res. 211: $90-98$

Obeid LM, Linardic CM, Karolak LA and Hannun YA (1992) Programmed cell death induced by ceramide. Science 259: $1769-1771$

Okazaki T, Bielawska A, Bell MR and Hannun YA (1990) Role of ceramides as a lipid mediator of $1 \alpha, 25$-dihydroxyvitamin $\mathrm{D}_{3}$-induced $\mathrm{HL}-60$ cell differentiation. J. Biol. Chem. 265: 15823-15831

Packhman G and Cleveland JL (1995) c-myc and apoptosis. BBA 1242: 11-28

Papp B, Zhang D, Groopman GE and Byrn RA (1994) Stimulation of human immunodeficiency virus type I expression by ceramide. AIDS Res. Hum. Retr. 7: $775-780$

Pearson BE, Nasheuer HP and Wang TSF (1991) Human DNA polymerase $\alpha$ gene: sequences controlling expression in cycling and serum-stimulated cells. Mol. Cell. Biol. 11: 2081-2095

Qin XQ, Chittenden T, Livingston D and Kaelin WG (1992) Identification of growth suppression domain within the retinoblastoma gene product. Genes Dev. 6 : 953-964

Sardet C, Vidal M, Cobrinik D, Geng Y, Onufryk C, Chen A and Weinberg R (1995) E2F-4 and E2F-5, two members of the E2F family, are expressed in the early phases of the cell cycle. Proc. Natl. Acad. Sci. USA. 92: 2403-2407

Sherr CJ, Kato J, Quelle DE, Matsuoka M and Roussel MF (1994) D-type cyclins and their cyclin-dependent kinases: $G_{1}$ phase integrators of the mitogenic response. In Cold Spring Harbor Symposia on Quantitative Biology, (Cold Spring Harbor Laboratory Press) pp. 11-19
Shiyanov P, Bagchi S, Adami G, Kokontis J, Hay N, Arroyo M, Morozov A and Raychaudhuri P (1996) p21 Disrupt the interaction between cdk2 and the E2Fp130 complex. Mol. Cell. Biol. 16: 737-744

Thalmeier K, Synovzik H, Mertz R, Winnacker EL and Lipp M (1989) Nuclear factor E2F mediates basic transcription and trans-activation by E1A of human MYC promoter. Genes Dev. 3: 527-536

Vairo G, Livingston DM and Ginsberg D (1995) Functional interaction between E2F-4 and 130 : evidence for distinct mechanisms underlying growth suppression by different retinoblastoma family members. Genes Dev. 9: 869-881

Venable ME, Lee JY, Smyth MJ, Bielawska A and Obeid LM (1995) Role of ceramide in cellular senescence. J. Biol. Chem. 270: 30701-30708

Verheij M, Bose R, Li XH, Yao B, Jarvis WD, Grant S, Birrer MJ, Szabo E, Zon LI, Kyriakis JM, Haimovitz-Friedman A, Fuks Z and Kolesnick RN (1996) Requirement for ceramide-initiated SAPK/JNK signalling in stress-induced apoptosis. Nature 380: 75-79

Wolff RA, Dobrowsky RT, Bielawska A, Obeid LM and Hannun YA (1994) Role of ceramide-activated protein phosphatase in ceramide-mediated signal transduction. J. Biol. Chem. 269: 19605-19609

Xiong Y, Hannon G, Zhang H, Casso D, Kobayashi R and Beach D (1993) p21 is a universal inhibitor of cyclin kinases. Nature 366: 701-704

Yang Z, Costanzo M, Golde DW and Kolesnick RN (1993) Tumor necrosis factor activation of the sphingomyelin pathway signals nuclear factor $\mathrm{kB}$ translocation in intact HL-60 cells. J. Biol. Chem. 268: 20520-20523

Yao B, Zhang Y, Delikat S, Mathias S, Basu S and Kolesnick RN (1995) Phosphorylation of Raf by ceramide-activated protein kinase. Nature 378: $307-$ 310 